\title{
ANALYSIS OF LEGAL AND ECONOMIC ASPECTS OF PRECIPITATION WEATHER DERIVATIVES FOR SERBIAN AGRICULTURAL SECTOR ${ }^{1}$
}

\author{
Janko Veselinović ${ }^{2}$ Todor Markovićc ${ }^{3}$,Stanimir Đukic ${ }^{4}$
}

\begin{abstract}
Summary
Weather derivatives are not present in Serbia nor in the neighbouring countries and have no significant application in the European Union, either. Weather derivatives originated in the USA, where the market for these instruments is most developed, in terms of both economy and law. However, positive effects of their application, through the decrease of influence of unfavourable weather conditions on agricultural crops, are a good basis for their further study. The most common reasons for their absence from our financial market are their complexity and the inexistence of prerequisites for their introduction. This paper analyses legal and economic aspects of weather derivatives, as forms of financial derivatives, as well as weather derivative contracts concluded with the aim of hedging against precipitation exposure. The goal of the analysis is to find an optimal contract structure, but also the conditions that have to be met in order for its signing to be economically justified for both contractual parties, as well as the creation of preconditions for this weather derivative contract to be the instrument of trade on the financial market. The paper also analyses normative frameworks for the conclusion of these derivative contracts, as well as the necessity to educate market participants,
\end{abstract}

1 The paper is a result of the research conducted within the project III-46006 of the Ministry of Education, Science and Technological Development of the Republic of Serbia titled Sustainable agriculture and rural development in order to achieve strategic goals Republic of Serbia in the Danube region and the project No. 47024 of the Ministry of Education and Science titled Social relations of Serbs and Croats, national identity and minority rights from the aspect of European integration.

2 Janko Veselinović, Ph.D., Associate Professor, University of Novi Sad, Faculty of Agriculture, Department of Agricultural Economics and Rural Sociology, Trg Dositeja Obradovića no. 8, 21000 Novi Sad, Serbia, Phone: +381 2148533 78, E-mail: veselinovic.janko@gmail.com

3 Todor Marković, Ph.D., Assistant Professor, University of Novi Sad, Faculty of Agriculture, Department of Agricultural Economics and Rural Sociology, Trg Dositeja Obradovića no. 8, 21000 Novi Sad, Serbia, Phone: +381 2148534 19, E-mail: todor@polj.uns.ac.rs

4 Stanimir Đukić, M.A., Ph.D. student at EDUCONS University, Faculty of Business Economy, Vojvode Putnika Street no. 87, 21208 Sremska Kamenica, Serbia, Phone: +381 6489248 81, E-mail: stanimirdj@hotmail.com

EP 2014 (61) 4 (1053-1067) 
which refers both to agricultural producers and financial institutions. Furthermore, it emphasizes the difference in relation to the classical contract of insurance against drought risk.

Key words: hedging strategies, precipitation quantity, weather derivatives.

JEL: $Q 12$

\section{Introduction}

Recent years have seen significant development of money market in Serbia and great progress has been made in the period 2000-2007, due to a significant liberalisation. Particular results were achieved in the field of money management. It is evident that foreign banks had a significant positive influence over such trends through a wide range of services offered to clients. There is certainly enough space left to improve the existing state and one of the ways to do so would be to introduce financial derivatives on the Serbian market.

Positive theories to explain financial risk management require a considerable number of assumptions concerning the objective of management (Benson and Oliver, 2004). The use of derivative instruments in corporate risk management has grown rapidly in recent years, caused partly by financial deregulation and partly by the success of the financial industry in designing a great variety of OTC and exchange-traded contracts (Fender, 2000). Financial derivatives (i.e. financial innovations) are, in fact, contracts traded on the stock market, like securities, the price of which depends on the price variations of securities or other assets derived from their active basis (i.e. underlying assets), (Carić et al., 2011). According to our law, financial derivatives can be a subject of public offering if they are approved by a decision of the stock market approved by the Committee on Payment and Settlement Systems (Veselinović, 2011).

Weather is undeniably one of the most important sources of risk in agriculture, and it seems that fluctuations of temperature and precipitation have even increased in the last decade due to global climate changes (Karl and Trenberth, 2003). Weather derivatives are a special kind of financial derivatives, the payment of which depends on a weather-related parameter. Weather derivatives are defined as futures contracts or futures contract options based on the weather index (precipitation amount, temperature, wind, frost, etc.) obtained by quantifying the deviation of weather conditions from the chosen point of reference. Weather derivatives were created to allow a transfer of risk of unfavourable weather conditions onto third persons that have the possibility to manage them efficiently. They are financial instruments that are not derived from the price of goods or some other financial category as a base value, but take weather variables, such as temperature or precipitation amount, instead (Marković and Jovanović, 2011a). Weather derivatives appeared at the end of the nineties, when financial experts began quantifying and indexing weather through monthly and season averages, then related those indexes to dollar value and started trading those packages (weather derivatives) on the stock market. 
Prior to that, this kind of trade was known in trade of indexes of other kinds (currencies, interest rates and agricultural goods). "The first weather transaction in 1996 opened the field of weather risk management, the value of which grew in the first several years of trade to over five million euro. From that moment on, financial anxiety due to unprofitable weather has become a commodity and, as such, placed the fear of ordinary, non-financially expressed weather under financial control (Janković, 2014)." The basic goal of weather derivatives is to reduce the uncertainty related to weather conditions in the future. Weather derivatives differ from the classical ones in that their purpose is to protect from a change in quantity (not the price) of goods and services offered by companies. The basis of other types of derivatives, thus, lies in assets or a commodity that is of value by itself, i.e. which is physically marketable (Ali, 2000). In this way, by means of these financial instruments, weather conditions are turned into a commodity (Marković, 2013; Janković, 2014). Companies use weather derivatives to protect themselves from unfavourable weather conditions, most often to smooth revenues, cover excess costs, reimburse lost opportunity costs, stimulate sales and diversify investment portfolios (Leggio, 2007).

Increase of certainty in agricultural production is one of the most important goals of every agrarian policy. In Serbian circumstances, uncertainty is reflected in unpredictability of prices of agricultural products, impossibility of marketing and collection of receivables, as well as insecurity reflected in insolvency of the warehouse owners and other economic risks. However, a specific uncertainty in agriculture is related to natural disasters, which, due to global climate changes, become significant risks. Some of them (drought, flood and hail) have had a significant impact on the crop yield and, in some cases, completely destroyed crops and fields. In addition to significant improvement in meteorology, weather conditions are still impossible to foresee in detail and much less to prevent. It is certain that Serbia has no adequate agrarian policy that would prevent the consequences of climate change and, on the other hand, nowhere nearly enough resources to cover or mitigate the damage resulting from it. In the past, insurance houses have avoided insuring against certain kinds of risk or have set, through their general and specific conditions, serious obstacles to potential policyholders.

On a global level, financial derivatives are also present as a model for increasing certainty in agricultural production. On the other hand, Serbian stock market still does not have all prerequisites for the introduction of financial derivatives into stock market offer (Veselinović et al., 2014). The goal of this paper is to shed some light on the problems related to introduction of financial derivatives, i.e. futures contracts, as their manifestation, into Serbian economic and legal system, thus creating conditions for their introduction into stock market offer. In order to gradually introduce financial derivatives and futures contracts into one of the Serbian stock markets, it is necessary for this type of business to gain recognition, as well as to recognise its difference from other similar legal institutions, such as insurance contract.

\section{Material and methods}

Scientific papers on the topic of financial derivatives (weather derivatives in particular) are very few in Serbia and there is a complete absence of integral research studies with analysis 
of stock markets, investment companies and agricultural producers, as potential participants in this market. The paper uses relevant sources by Serbian authors who dealt with theoretical and practical aspects of application of weather derivatives, as well as the sources by foreign authors. Hence, this paper uses the comparative legal method and comparative economical method to compare the experience of other countries and Serbian legislation and practice in this field. Starting from the economic and legal institutes in other countries, conclusions were made on their position in Serbian legislation or absolute exclusion and their inexistence in practice. The paper includes an analysis of weather derivatives with a more detailed analysis of weather derivative contract, which is based on a smaller amount of precipitation. The paper also analyses legal framework related to this field.

\section{Results and discussion}

\section{Conditions for introduction of weather derivatives onto Serbian financial market}

Weather derivatives, like financial derivatives in general, were made as an answer to the growth of risk on the market, but they can also present a significant source of numerous dangers. Hence the role of the state is very important in order to promote use of weather derivatives for hedging strategies, instead of potentially leading to new risks, primarily on the financial market. Weather derivatives create such conditions that the consequences of negative climate fluctuations do not greatly reflect on the total profit generated from production, which is particularly true in agriculture. In Serbia, as a rule of thumb, negative climate conditions lead to the growth of basic products, thus increasing prices in the production and market chain.

Seeing as weather derivatives are based on the concept of futures stock market contract, i.e. that with a time distance between the moment it is signed and the moment of its fulfilment, contractual fulfilment can be traded in the interim period. Payment or settling is done upon the fulfilment of futures contracts, with the traders paying the positive or negative difference arising from the business (Gardner, 2003).

The paper treats the lack of precipitation in the previous years as the object of the weather derivative contract. Taking into account any crop (such as mercantile corn), it is required that, apart from the regulatory conditions, we also have a stock market institution specialised in such trade. On the other hand, existence of stock market participants is required, both sellers and buyers of the futures contracts, trading in weather conditions as a commodity. In order to entirely apply a futures contract, for someone to merely make a "futures" purchase of "weather conditions", does not suffice, but also to allow someone to potentially buy out a futures contract, accepting the risk of "weather conditions". A stock market trade of a certain weather derivative is not necessary, as these contracts can also be traded out of stock markets (Marković and Jovanović, 2011b). It is evident that the futures trade can have a speculative character, thus the role of states is very important. In this field, appropriate directives of the EU are instructive, as well as the recommendations of the Bank supervision committee of the International Payment bank in Basel. 
Analysis of legal and economic elements of futures contracts, an example of insurance against an insufficient amount of precipitation

Anxiety caused by uncertain future, due to unpredictable climate conditions is known in the world of finances under the name of weather derivatives, which are stock market products aimed at weather trading. They are one of the instruments of protecting agricultural workers from a lower precipitation level compared to a multiannual average. This is realised by an agricultural producer signing a weather contract with an insurance company or another authorised financial organisation. In the economic sense, weather derivatives are isolated from the political and economic instabilities, hence there is no obstacle to trading weather derivatives on the Serbian market in the future, especially seeing as their price is not related to supply/demand ratio. On the other hand, legally, these instruments are a form of contingent, i.e. possible rights to other forms of financial assets, which can be reflected in financial compensation if contract conditions are met.

The first and the greatest market of weather derivatives is the Chicago Mercantile Exchange $-\mathrm{CME}$, which allows trading in a majority of agricultural products. The table also shows an overview of other stock markets trading in weather derivatives with a list of offered products (Table 1).

Table 1. World futures and options market in agricultural commodities

\begin{tabular}{|c|c|c|}
\hline Exchanges & $\begin{array}{c}\text { Location and Date of } \\
\text { Establishment }\end{array}$ & Agricultural Products Offered \\
\hline $\begin{array}{l}\text { Chicago Board of Trade } \\
(\text { CBOT) }\end{array}$ & Chicago (1848) & $\begin{array}{l}\text { Corn, soybeans, soybean oil, soybean } \\
\text { meal, wheat, oats, rough rice, mini } \\
\text { corn, mini soybeans, mini wheat }\end{array}$ \\
\hline $\begin{array}{l}\text { Kansas City Board of } \\
\text { Trade (KCBOT) }\end{array}$ & Kansas (1856) & Wheat \\
\hline $\begin{array}{l}\text { New York Board of Trade } \\
\text { (NYBOT) }\end{array}$ & New York (1870) & Cocoa, coffee, cotton, FCOJ, sugar \\
\hline $\begin{array}{l}\text { Chicago Mercantile } \\
\text { Exchange }(\mathrm{CME})\end{array}$ & Chicago (1874) & $\begin{array}{l}\text { Beef, dairy, e-livestock, fertilizer, } \\
\text { hogs, lumber }\end{array}$ \\
\hline $\begin{array}{l}\text { Minneapolis Grain } \\
\text { Exchange (MGE) }\end{array}$ & Minneapolis (1881) & $\begin{array}{c}\text { Wheat, hard winter wheat index } \\
\text { (HWI), soft winter wheat index (SRI), } \\
\text { spring wheat index (SWI), national } \\
\text { corn index (NCI), national soybean } \\
\text { index (NSI) }\end{array}$ \\
\hline $\begin{array}{l}\text { Sydney Futures Exchange } \\
\text { (SFE) }\end{array}$ & Sydney (1960) & $\begin{array}{c}\text { Wool, New Zealand Broad Wool, } \\
\text { MLA/SFE cattle }\end{array}$ \\
\hline $\begin{array}{l}\text { Winnipeg Commodities } \\
\text { Exchange }\end{array}$ & Winnipeg (1972) & Canola, Barley, Flaxseed, Feed wheat \\
\hline $\begin{array}{l}\text { South African Futures } \\
\text { Exchange (SAFEX) }\end{array}$ & Sandown (1988) & $\begin{array}{c}\text { White maize, yellow maize, wheat, } \\
\text { sunflower seed, soybeans }\end{array}$ \\
\hline $\begin{array}{l}\text { Budapest Commodity } \\
\text { Exchange }\end{array}$ & Budapest (1989) & $\begin{array}{l}\text { Corn, wheat, feed barley, rapeseed, } \\
\text { soybean, sunflower seed }\end{array}$ \\
\hline
\end{tabular}




\begin{tabular}{|l|l|c|}
\hline \multicolumn{1}{|c|}{ Exchanges } & $\begin{array}{c}\text { Location and Date of } \\
\text { Establishment }\end{array}$ & Agricultural Products Offered \\
\hline $\begin{array}{l}\text { Poznan Commodity } \\
\text { Exchange }\end{array}$ & Poznan (1991) & Corn, wheat, sugar \\
\hline Warenterminbörse & Hanover (1998) & $\begin{array}{c}\text { Hogs, piglets, potatoes, wheat, } \\
\text { brewing barley }\end{array}$ \\
\hline Euronext.liffe & $\begin{array}{l}\text { London, Paris, } \\
\text { Amsterdam, Lisbon \& } \\
\text { Brussels (2000) }\end{array}$ & $\begin{array}{c}\text { Cocoa, Robusta coffee, white sugar, } \\
\text { feed wheat, milling wheat, rapeseed, } \\
\text { corn, potatoes }\end{array}$ \\
\hline
\end{tabular}

Source: Battley, 1999.

Serbian Law on the Capital Market (Zakon o tržištu kapitala) defines the following financial instruments: "Options, futures, swaps, forward rate agreements and any other derivative financial instruments relating to climatic variables, freight rates, inflation rates, emission allowances or other official economic statistics that must be settled in cash or may be settled in cash at the option of one of the parties ..." (Law on the Capital Market, 2011, Article 2, paragraph 1, item 1, sub-item 10).

Jobs related to offer and sale of financial instruments, without obligatory buyout are classified, according to Serbian legislation, under investment services and activities and can be performed by qualified investors that fulfil legal conditions. Those are legal entities, that are authorized by a relevant supervisory body or are subject to supervision on a financial market including: credit institutions, investment companies, other financial institutions whose operations are approved or supervised by a relevant supervisory body, insurance companies, collective investment undertakings and their management companies, pension funds and their management companies, dealers in commodities (Law on the Capital Market, 2011, article 14).

Weather derivative contracts are classified under the financial derivative group of contracts and their legal nature is informal, seeing as their form is not standardised in positive laws. This means that, when signing of such a contract, it is important that it contain such elements as enable it to be fulfilled, as well as that it be harmonised with the national legal system. It is also important to take into account the Securities Act (Zakon o tržištu hartija od vrednosti i drugih finansijskih instrumenata), (2006), as well as the Law on Banks (Zakon o bankama), (2005) and the Law on Investment Funds (Zakon o investicionim fondovima), (2006), etc. If weather derivative contracts were to be made, they, with the presumption that they would be traded on the stock market, they would have to be formalised, seeing as stock markets of financial derivatives trade in formal derivatives, exclusively. If a contract was made for trade on a non-stock market, it could be tailored completely according to user needs. The first derivative contracts in the world appeared in non-stock markets, as privately arranged business between two parties, hence it can be expected that in the future, these contracts will appear on our market, too, in the same way. Similar contracts from comparative law could be taken as 
models, although their incorporation should be carefully planned, seeing as they need to be realised within our legal systems and by existing subjects in the financial market.

The paper covers weather derivatives that are based on insufficient precipitation compared to the referential multiannual average. In this way, weather contracts based on excessive precipitation, as well as other contracts related to other weather parameters could be considered (wind, snow, cloudiness, etc.). As for the application of weather derivatives, certain authors claim that it most commonly lies in insurance of those crops that give markedly high yields or those significantly represented in the overall structure of sowed fields (Marković, 2013).

In order to trade in weather derivatives, a standardised contract needs to be created. On the one hand, buyers of climatic variables (precipitation amount) can be companies, agricultural cooperatives, entrepreneurs, registered agricultural holdings or even a physical person that has not registered an agricultural holding. This can be any legal or physical person with the interest in insuring against uncertainty of insufficient precipitation that could adversely affect the yield. Individual agricultural holding from Đurđevo can be taken as an example, with their official address and other data. On the other hand, a seller of climatic variable could be any legal person registered for doing trading business with financial derivatives. Investment fund from Belgrade, with their official address and other data can be taken as an example.

Weather derivative contracts have a point of activation of obligations of contractual parties, which means that one or the other party "gains" an obligation only after it has been established, on the basis of observation of recorded precipitation on a referential weather station, that the precipitation quantity is below or under certain reference values. Contract on weather derivatives needs to have a clearly established contract subject, which could be: Payment of certain sum due to insufficient precipitation in the referential measurement period (e.g. 01.V-31.VIII) in relation to referential multiannual precipitation for a particular $\operatorname{crop}^{5}$ (e.g. commercial corn) of an agreed area in the cadastral community of Đurđevo. The contract must precisely establish what is meant by insufficient precipitation amount.

Seeing as climatic variables cannot be traded separately, they need to be quantified. In this example, it refers to the precipitation amount in $\mathrm{mm}$. We thus obtain the index, which can be an object of trade. In later text, elements necessary for index determination are cited. In the contract it would be necessary to define the way precipitation amount is calculated if,

5 When defining the contract subject, a referential multiannual average precipitation (for the same period) needs to be established. It is determined for every risk zone (that can precisely match the cadastre unit) and established on the basis of multiannual daily precipitation index, as officially recorded by the Republic Hydro-meteorological Service. Referential multiannual average precipitation refers to the product of coefficient of 1.45 and average values of 10 lowest precipitation amounts recorded during the referential period, for each year from 1961 to 2014, based on data made available by the Republic Hydro-meteorological Service and rounded down to one decimal place. Referential multiannual precipitation amount is determined for each individual referential time period and every single zone of drought risk, separately (special circumstances for crop and yield insurance against drought risk, Generali Insurance, Serbia a.d.o., 2014).

EP 2014 (61) 4 (1053-1067) 
for any reason, no data on daily precipitation is recorded on any certain day at a referential weather station during the period of measurement or if it is not available in official reports of the Republic Hydro-meteorological Service, alternative piece of data can be defined as a piece of data from an alternative weather station, which can be the nearest one. The contract can define the said alternative place, as well. If precipitation amount cannot be established in this way, either, multiannual average daily precipitation for that day can be used based on 10 -year records for that day at that weather station.

One of the elements of the contract should define the referential weather station, i.e. the referential climatological or weather station of the Republic Hydro-meteorological Service. It must belong to a specific cadastral municipality defined on the policy or to the territory of the neighbouring cadastral municipality. It is possible for one contract to contain more weather stations for different parcels, thus more risk zones, as well. It is also possible to separate the contracts according to weather stations and risk zones.

Within the referential period, times when precipitation is measured also need to be defined. These can also be termed measurement periods. Measurement periods are most commonly taken as periods of 10 to 11 successive days during a calendar month and they are defined in such a way that each calendar month contains three measurement periods. Thus, within a referential time period, we have more measurement periods. Referential precipitation amount is a sum of all referential precipitation amounts in the measurement period during the referential time period at the climatological station of the Republic Hydro-meteorological Service.

Another important contract element is the price payable by the buyer of the climatic variable to the seller, as a premium used to insure against the insufficient precipitation. During the construction of the weather derivatives, the key question is setting the risk price (fair premium) that the buyer is ready to pay for the risk transfer. Premium paid depends on the type and structure of the weather derivative (Marković, 2013). Premium, as a rule, is established according to the area cultivated and could be subject to agreement between the parties, but some already established rules are used instead. In order to define the premium, the method of simulation based on long-term data is used, where the fair premium equals the discounted expected value of payment from the weather derivative (Marković and Jovanović, 2011b). The question of payment arising from the weather is established in the following step and the very discount process is used to calculate the value of the future payment for a certain moment in the past (establishing the current premium value on the basis of the payment expected in the future).

The following element of the contract would be the compensation paid by the seller of the weather variable to the buyer for an insufficient precipitation amount in relation to the referential precipitation of the previous years. It is important to establish what the border level is, as it marks the index value that triggers the payment. This compensation could be defined according to millimetres of precipitation level below average. An important aspect is also that of the function of payment, which brings the established index into cash flow or to payment of a certain overall money value (Marković and Jovanović, 2011b). 
Thus, for example, if the referential multiannual precipitation amount is $100 \mathrm{~mm}$ and the yearly precipitation amount in the chosen period is $80 \mathrm{~mm}$, the seller should pay the buyer for the precipitation level difference $(20 \mathrm{~mm})$ multiplied by the money value of $1 \mathrm{~mm}$ of precipitation, as determined by contract. In this weather contract, precipitation differences payable by the seller could also be defined in a different way. This is precipitation difference between the referential multiannual precipitations and precipitations in the referential period. It can be explained on a following example: for every $10 \mathrm{~mm}$ less precipitation, a certain sum is paid, for every $20 \mathrm{~mm}$ less precipitation, another, larger sum, is paid, and so on, until the previously agreed maximum payment (e.g. $50 \mathrm{~mm}$ less precipitation). The contract limits the maximum payment below or above the defined index value. The compensation scale is thus defined in relation to the "drought" intensity.

A referential multiannual precipitation amount is a starting point for "defining" mathematical difference in relation to precipitation amount that the contract defines. The contract also needs to define the way of establishing a referential maximum precipitation amount in the measurement period, i.e. the insurance period. The referential maximum precipitation amount in the measurement period is the amount of precipitation during the measurement period (cumulative for the measurement period). If during a measurement period greater amounts of precipitation than the defined maximum are recorded (extreme showers, torrential rains etc.), the upper limit is defined as the maximum precipitation amount in the measurement period. Referential maximum precipitation amount in the measurement period is determined for every risk zone separately.

As all other contracts, weather derivative contract should also contain basic elements, including the time and place of signing and the competent court or arbitration court (Table 2).

Table 2. Weather derivatives contract

\begin{tabular}{|ll|}
\hline \multicolumn{2}{|c|}{ WEATHER DERIVATIVE CONTRACT } \\
\hline \multicolumn{2}{|c|}{ Signatory parties } \\
Agricultural holding of Jovan Petrović & Delta investment \\
Marka Popovića 44, Đurđevo, Serbia & Koče Racina 3, Belgrade Serbia \\
(Buyer of the climatic variable) & (Seller of the weather variable) \\
\hline
\end{tabular}

Article 1.
\[ \text { Subject of the contract } \]
The subject of this contract is the payment of financial compensation by the Seller of the
weather variable to the Buyer of the weather variable due to an insufficient precipitation amount
in the referential measurement period, pertaining to the parcels (parcel cadastral number) in
the cadastral community of Đurđevo with the total area of 150 ha on which mercantile corn
will be sown in 2015. The basis for payment is the difference in precipitation amount in the
referential measurement period of 01 .V 2015 to 31 .VIII 2015 in relation to the referential
multiannual precipitation amount in the period of 01 .V 2015 to 31 .VIII 2015 in the area of
cadastral community of Đurđevo.

EP 2014 (61) 4 (1053-1067) 
Article 2.

Referential period

Referential measurement period is from 01 .V 2015 to 31 .VIII 2015 in relation to referential multiannual precipitation amounts in the period of 01.V 2015 to 31.VIII 2015. The referential multiannual precipitation amount is the product of the coefficient of 1.45 and the average value of 10 lowest precipitation amounts measured during a referential time period, for each individual year in the period from 1961 to 2014, based on the data of the Republic Hydrometeorological Service and rounded down to one decimal place.

The contract defines what insufficient precipitation is.

\section{Article 3.}

Referential weather station

Referential weather station, climatological station or meteorological station of the Republic Hydro-meteorological Service is the station n. 746 in the cadastral community of Đurđevo on the parcel (parcel No).

If, for any reason, no data on daily precipitation is recorded on any certain day at a referential weather station during the period of measurement or if it is not available in official reports of the Republic Hydro-meteorological Service, data from the alternative weather station nearest to the cadastral community of Žabalj, which is located on the parcel (parcel No). If the precipitation quantity cannot be established in this way, either, multiannual average daily precipitation for that day (based on ten-year records for that day at the weather station of the cadastral community of Đurđevo) will be taken as an additional alternative piece of data on daily precipitation amount.

\section{Article 4. \\ Premium}

The Buyer of the climatic variable pays the variable Seller the premium used to insure against a smaller precipitation amount in the amount of .......RSD per ha, to a total of ......RSD. The Premium is payable on defined dates: (define the dates of premium payments)

Compensation for insufficient precipitation
The Seller of the weather variable shall pay the compensation to the Buyer of the weather
variable for an insufficient precipitation amount in relation to the referential precipitation in
the previous years, if conditions of the precipitation border level are met, in the following
way: Border level for compensation is $20 \mathrm{~mm}$ less precipitation in relation to the referential
multiannual average. For every mm of precipitation below the borderline, the Seller of the
weather variable shall pay the Buyer of the sum of .......RSD per ha, to a total of ......RSD.
A total compensation is defined according to the following formula: smaller precipitation
amount in mm x .......RSD per mm x number of hectares = overall compensation sum .......RSD.
Maximum payment is up to 50 less mm of precipitation in relation to the multiannual average,
which means that the Seller of the weather variable is obliged to pay the compensation only
up to that value index.




\section{Article 6.}

Referential index

Referential index for compensation for smaller precipitation amounts is less precipitation (rainfall) per $\mathrm{mm}$, below the border level of $20 \mathrm{~mm}$ in relation to the multiannual referential precipitation level at the defined weather station.

\begin{tabular}{|l|}
\hline \multicolumn{1}{c|}{ Article 7.} \\
Index trade freedom \\
$\begin{array}{l}\text { Signatory parties agree to a free trade of this contract, i.e. its referential index on the stock and } \\
\text { non-stock markets. }\end{array}$ \\
\hline
\end{tabular}
non-stock markets.

\section{Article 8.}

\section{Settlement of disputes}

In order to settle disputes arising from this contract, the competent arbitration is ad hoc, as defined by the signatories in that each signatory will name an arbitrator, with those arbitrators naming the third one, who will preside over the ad hoc arbitration. The ad hoc arbitration decision has the validity of an enforceable court judgment. Ad hoc arbitration will adhere to the rules of the Foreign trade arbitration of the Serbian Chamber of Commerce.

Article 9.

Number of copies of the contract

The contract is concluded in 4 (four) copies, of which each signatory retains 2 (two) copies.

Article 10.

Time and place of contract conclusion

The contract is concluded in Belgrade on 17.10. 2014.

Buyer of the weather variable

Signature
Seller of the weather variable

Signature

Source: Established by author's

\section{Differentiation of weather contract from insurance contract}

The basic difference between the weather derivative contract on purchase of "weather future", based on the prevention of risk of insufficient precipitation amount (drought) and the contract of drought insurance is reflected in the fact that with weather contracts, the important factor is not the extent of drought damage, but the precipitation amount smaller than the multiannual referential period. As opposed to the weather contract, with insurance contract, the fact that the referential precipitation amount is lower than the referential multiannual precipitation amount is only the prerequisite to begin the damage assessment and only if it is established that in the zone insured against the drought risk there was a decrease of the agreed yield (most often more than 10\%), the damage compensation is paid. Thus for both the seller and the buyer of the weather 
contract, when it comes to the payment of compensation, the real drought damage is unimportant, but it is important that the precipitation amount for the agreed period was less than the multiannual referential period.

In this regard, this weather contract is equally speculative as any other financial derivative. Trading in these financial derivatives carries a risk that is difficult to foresee. Seeing as the results of purchase of this weather contract are related to an unknown future event (the amount of rainfall on these parcels), it is not difficult to conclude that each purchase and sale of a weather contract is in itself a significant risk. This makes it speculative by nature, which does not mean that trading in these financial derivatives is always speculative from the aspect of intent of its participants. Classical insurance does not recognise the possibility of existence of speculators, seeing as speculation is a sanctioned offense in insurance business.

On the other hand, according to the Securities Act, article 3, the financial instruments do not include insurance and reinsurance policies and other products of insurance companies. The insurance contract, although sui generis, is classified under commodity trade. The very legal definition of insurance contract makes a clear difference in relation to other similar jobs. "By a contract of insurance a negotiator of insurance shall assume the obligation to pay a specific amount to an insurance organisation (insurer), while the organisation shall assume the obligation, should an event take place which represents the case covered by insurance, to pay to the insured person, or to a third party, compensation, the stipulated amount, or to do something else" (the Law of Contract and Torts), 1978, article 897). The mutuality and solidarity are not immanent to weather derivatives, as the fact that compensation is paid regardless of the extent of damage and without the estimate of that damage shows that it is a legal form based on other principles. Weather derivatives are thus a special category of financial instruments.

It is apparent that it must be admitted that weather derivatives that are used to insure crops against insufficient precipitation amount or other adverse weather conditions contain many elements of insurance contracts. This makes these two legal forms similar and it is important to emphasize the differences that make these two contracts and legal forms different. From the economic point of view, the difference between weather contracts and insurance contracts is that "weather derivatives cover harmful events of low-risk level, but of high probability of occurrence, while insurance covers harmful events of high-risk level, but of low probability of occurrence" (Marković, 2013). In this respect, weather derivatives, unlike insurance, presume that a temperature deviation of merely several degrees Celsius or several $\mathrm{mm}$ of precipitation can endanger yields and income.

\section{Conclusion}

On the basis of analysis of regulations and state of stock markets in Serbia, one could conclude that there are still no conditions necessary for the application of weather derivatives and their presence on this stock market. In order to create conditions for their use, primarily in terms of weather derivative contracts, it is necessary to realise numerous preconditions. It is of primary 
importance to research and survey the opinions of the national stock markets and the attitudes of the national investment companies on basic indicators related to weather derivatives. In addition to that, it is important to acquaint potential users with the economic and legal aspects of weather contracts, including the creation of standard contracts for weather derivatives. Insufficient knowledge on weather derivatives entails a high level of standardisation of weather derivatives in order to create conditions for their faster introduction to the market. On the other hand, it is necessary to create adequate technical preconditions on the stock market, but also enable the specialisation of certain investment funds in order to operate with them.

It can be concluded from the analysis that it is necessary to shed some additional light on economic effects of introduction of weather derivatives on capital market in the field of agricultural products. It is also very important to get both sellers and buyers interested in such financial arrangements. The basic precondition for this is the expansion of knowledge on these financial instruments through counselling, seminars, education, etc., as well as through the creation of requirements through additional equipment of stock markets and other financial institutions.

\section{Reference}

1. Ali, P. U. (2000): Weather Derivatives, Hedging Volumetric Risk and Directors Duties, Company and Securities Law Journal, University of Melbourne - Low School, vol. 18, pp. 151-155.

2. Battley, N. (1999): The world's futures and options markets, Second Edition, John Wiley \& Sons, LTD, Chichester.

3. Benson, K., Oliver, B. (2004): Management Motivation for Using Financial Derivatives in Australia, Australian Journal of Management, vol. 29, no. 2, pp. 225-242.

4. Carić, S., Vitez, M., Raičević, V., Veselinović, J. (2011): Privredno pravo, Fakultet za ekonomiju i inženjerski menadžment, Novi Sad.

5. Fender, I. (2000): Corprate Hedging: The Impact of Financial Derivatives on the Broad Credit Channel of Monetary Policy, BIS working papers, no.94, Basel, Swizerland, pp. 1-26, available at: http://www.bis.org/publ/work94.pdf

6. Gardner, L. (2003): New Options for Managing Agricultural Weather Risk, CPCU eJournal, 56(8):1-23.

7. Generali Insurance Serbia a.d.o. (2014): Posebni uslovi za osiguranje useva i plodova od rizika suše, TN-U-09-OU-14-03.

8. Janković, V. (2014): Klima i finansijski proizvodi: Kome je vreme uzelo meru. Biznis\&finansije, available at: http://bif.rs/2014/07/klima-i-finansijski-proizvodi-komeje-vreme-uzelo-meru/

9. Karl, T. R., Trenberth, K. E. (2003): Modern Global Climate Change, Science, vol. 302, pp. 1719-1723.

10. Leggio, K. B. (2007): Using weather derivatives to hedge precipitation exposure, Managerial Finance, University of Missouri at Kansas City, 33(4):246-252.

EP 2014 (61) 4 (1053-1067) 
11. Marković, T. (2013): Vremenski derivati i upravljanje rizikom u poljoprivredi, Univerzitet u Novom Sadu, Poljoprivredni fakultet, Novi Sad.

12. Marković, T., Jovanović, M. (2011a): Risk Management in Plant Production with Weather Derivatives, Contermporary Agriculture, Novi Sad, 60(1-2):1-6.

13. Marković, T., Jovanović, M. (2011b): Rainfall insurance in wheat production with weather derivatives, Economics of Agriculture, IAE, Belgrade, 58(2):179-189.

14. Veselinović, J. (2011): Privredno pravo, Univerzitet u Novom Sadu, Poljoprivredni fakultet, Novi Sad.

15. Veselinović, J., Marković, T., Ivanović, S., Vasiljević, Z., Uçar, K. (2014): Economic and Legal Analysis of Financial Derivatives in terms of Increasing Certainty in Agricultural Production in Serbia, Book of Abstracts of $25^{\text {th }}$ International ScientificExpert Congress on Agriculture and Food Industry, Izmir, Turkey, September 25-27 ${ }^{\text {th }}$, p. 228.

\section{$\underline{\text { Legislation }}$}

16. Law of Contract and Torts, Official Gazette of Republic of Serbia, no. 29/78, 39/85, 45/89 - decision USJ and 57/89, Official Gazette of SRY, no. 31/93 and Official Gazette of SCG, no. 1/2003 - constitution, article 897.

17. Law on Banks, Official Gazette of Republic of Serbia, no. 107/05, 91/ 2005.

18. Law on Investment Funds, Official Gazette of Republic of Serbia, no. 46/2006, $51 / 2009,31 / 2011$.

19. Law on the Market Capital, Official Gazette of Republic of Serbia, no. 31/2011.

20. Securities Act, Official Gazette of Republic of Serbia, no. 47/2006. 


\title{
ANALIZA PRAVNIH I EKONOMSKIH ASPEKATA VREMENSKIH DERIVATA KOD PADAVINA U SRBIJI U POLJOPRIVREDNOJ OBLASTI
}

\author{
Janko Veselinovićb, Todor Markovićc ${ }^{7}$, Stanimir Đukićc \\ Rezime
}

Vremenski derivati nisu zastupljeni u Srbiji i njenom okruženju, a nemaju primenu u značajnoj meri ni u Evropskoj uniji. Mesto njihovog nastanka, ali i ekonomskog i pravnog razvoja su SAD. Međutim, pozitivni efekti njihove primene, kroz smanjivanje uticaja nepovoljnih vremenskih prilika na poljoprivredne useve, predstavljaju dobro osnovuza dalje njihovo izučavanje radi moguće primene u praksi. Najčešći razlozi njihovog neprisustva na našem finansijskom tržištu su njihova složenost, ali i nepostojanje pretpostavki za njihovo uvođenje. $U$ ovom radu se analiziraju pravni i ekonomskih aspekti vremenskog derivata, kao vrste finansijskih derivata, kao i vremenskog derivativnog ugovora koji se zaključuje sa ciljem smanjivanja neizvesnosti usled manje količine padavina. Cilj analize je odgovor na pitanja koja se tiču strukture ugovora, ali i uslova koji moraju da budu ispunjeni da bi njegovo zaključivanje imalo ekonomsku opravdanost za obe ugovorne strane, ali i stvaranje uslova da taj vremenski derivat, u formi ugovora, bude predmet trgovine na finansijskom tržištu. U radu se analizira i normativni okvir za zaključenje ovih derivativnih ugovora, ali i neophodnost edukacije učesnika na tržištu, što se odnosi i na poljoprivedne proizvođače i na finansijske institucije koje bi ovim poslom mogle da se bave. Takođe, naglašava se $i$ razlika u odnosu na klasični ugovor o osiguranju od rizika suše.

Ključne reči: hedžing strategije, količina padavina, vremenski derivati.

6 Prof. dr Janko Veselinović, Univerzitet u Novom Sadu, Poljoprivredni fakultet, Departman za ekonomiku poljoprivrede i sociologiju sela, Trg Dositeja Obradovića 8, 21000 Novi Sad, Republika Srbija, Telefon: +3812148533 78, E-mail: veselinovic.janko@gmail.com

7 Doc. dr Todor Marković, Univerzitet u Novom Sadu, Poljoprivredni fakultet, Departman za ekonomiku poljoprivrede i sociologiju sela, Trg Dositeja Obradovića 8, 21000 Novi Sad, Republika Srbija, Telefon: +381 2148534 19, E-mail: todor@polj.uns.ac.rs

8 Stanimir Đukić, M.A., doktorant, Univerzitet EDUCONS, Fakultet poslovne ekonomije, Vojvode Putnika 87, 21208 Sremska Kamenica, Srbija, Telefon: +381 6489248 81, E-mail: stanimirdj@hotmail.com

EP 2014 (61) 4 (1053-1067) 